\title{
Texts and Objects: The Books of the Schocken Publishing House in the Context of their Time
}

\section{Introduction}

\begin{abstract}
Books are not absolutely dead things but doe contain a potencie of life in them to be as active as the soule whose progeny they are; nay they do preserve as in a violl the purest efficacie and extraction of that living intellect that bred them. (Milton 1644) ${ }^{1}$
\end{abstract}

John Milton argued in this 1644 speech that books have an existence independent of their authors. According to the English poet, books turn into living creatures beyond the text they contain. Following this line of thought, this article addresses the topic of German-Jewish literature in times when German-Jewish life and culture were being suppressed, ostracized, persecuted and annihilated. Its focus is the production of the Berlin Schocken publishing house, which was founded in 1931 by Salman Schocken, a wealthy owner of a chain of department stores in Germany and an important cultural Zionist. Only seven years later, at the end of 1938, the publishing house was closed down by the National Socialist regime. The Schocken Verlag Berlin is a consummate symbol of German-Jewish literary culture during the first half of the Nazi dictatorship. Salman Schocken, together with his managing director Lambert Schneider, chief editor Moritz (later Moshe) Spitzer and freelance editor and consultant Martin Buber, published just under 200 titles, including bilingual editions of traditional Jewish religious texts, folklore, reproductions of rare prints, Hebrew poetry and books by contemporary writers such as Samuel Joseph Agnon, Ludwig Strauss, and Karl Wolfskehl. ${ }^{2}$

In this paper I focus on German-Jewish literary culture as presented in the program of the Schocken Verlag. This perspective allows us to study the role of literature as an actor in the social and cultural history of a specific period. The field of book history has demonstrated that books have a social function beyond the texts they contain. Robert Darnton, one of the theoretical founders of the field, defined the book as an active force in human history (1982). For him,

1 Here quoted from Hales $(1904,5)$.

2 The complete bibliography of books published by Schocken Verlag Berlin can be found in Dahm (1979, 473-501). 
the history of the book is first and foremost a "cultural history of communication by print" (Howsam 2006, 28f.). In this circuit of communication, the book is the mediator of relationships between people: "The circuit runs full cycle. It transmits messages, transforming them en route, as they pass from thought to writing to printed characters and back to thought again..." (Darnton 1982, 67). While Darnton's idea to study the communication circuit to understand the role of the book in society is fertile, the complete averting from the text, the content of the book, seems problematic. Understanding the book as an abstract mediator in a structure of communication opens up new approaches and leads to new insights that are of the utmost relevance for the study of societies, but the complete suppression of the book as a carrier of culture and discourse neglects an important factor in the studies of individuals and communities.

Leslie Howsam defines the book as "simultaneously a written text, a material object, and a cultural transaction" (2006, vii). Not without reason, Benedict Anderson states in Imagined Communities that people who read texts in approximately the same time constitute a community without knowing each other personally. The book trade was a "silent bazaar," which linked producers and consumers likewise to a community with its own identity (Anderson 2006, 77). The study of the book calls for an integrated approach that includes historical perspective as well as insights from literary studies. Textuality and history need to be studied inclusively to understand the role of books in societies. For the subject of this paper, this approach seems promising. It not only combines cultural and social history but also helps to understand the importance that the book - both as physical object and as text - carried for German Jewry between 1933 and 1945. This paper aims to understand the production of these books as well as their cultural and social context.

Books are means of encounter and exchange: In the case of the Schocken publishing house during the Nazi era, they had three key roles. First, they built a bridge between Jews and non-Jews through the collaboration between the publisher and skilled artisans, despite the National Socialist policy to exclude Jews from social and cultural interactions with non-Jews. Studying the production process of Schocken books allows us to address the encounter of two otherwise forcibly separated social groups. Second, Schocken books unified the GermanJewish community and made assimilated Jews more culturally and traditionally literate by providing traditional texts in translation and editions with accessible explanations. By understanding books as an important factor in community building, we can trace their importance for persecuted German Jews. Third, a significant number of publications from the Schocken Verlag voiced resistance 
to the National Socialist regime by applying a method deeply enrooted in the Jewish theological tradition and contextualised exegesis of religious texts. These three aspects will be dealt with in detail through analysis of several exemplary publications.

\section{Books as mediators of relationships: producing Jewish books in Nazi Germany}

Despite the harsh anti-Jewish policies that the National Socialist state implemented immediately after Adolf Hitler rose to power in end of January 1933, it remained possible to publish Jewish content books in Germany until the end of 1938. However, the conditions for publishing were, to put it mildly, not simple. On 10 May 1933, books viewed as opposing Nazism were burnt in twenty-two university cities across Germany. The book-burning was organized as a nationwide "Campaign against the Un-German Spirit" (Aktion wider den undeutschen Geist) by the Main Office for Press and Propaganda of the German Student Union and was supported by leading Nazis such as Joseph Goebbels, who delivered a speech on the occasion of the auto-da-fé in Berlin, where some 40,000 people gathered to witness the burning of the books (Sauder 1983; Sauder 1985). Even though the Aktion was not organized by the party or the government (Barbian 1995, 139f.; Dahm 1986, 58), the separation of undesired literature was considered an important factor in the völkisch revival of the German people. Already on 5 April 1933, Hans Hinkel, an SS officer and member of the Blood Order and Reich Organization Leader of the Militant League for German Culture (Kampfbund für deutsche Kultur), organized an evening under the motto "Book and Spirit" (Buch und Geist). The subject of this gathering was how to achieve the national revolution in the fields of literature and book trade (Sauder 1983, 105).

Books by Jewish authors were indexed and burned together with texts of communist, Marxist, liberal, democratic and exiled authors, to name just a few relevant categories. The "Campaign against Un-German Spirit” was perceived as a serious threat within the Schocken publishing house. On 23 May Lambert Schneider wrote to the important German-Jewish scholar of Kabbalah Gershom Scholem, who had lived in Jerusalem since the early 1920s, "that all plans in the publishing house were suspended as long as it was uncertain if the publishing house will be able to continue its work." Nevertheless, he told Scholem that the Schocken publishing house was very much interested in working with him and 
asked how fast Scholem would be able to finish "the single volumes." 3 Schneider was referring to a conversation between Salman Schocken and Gershom Scholem in which the two men agreed that Schocken would publish a five-volume study on Kabbalah by Scholem. ${ }^{4}$ Just a few days earlier, Schneider also contacted Samuel Joseph Agnon because he heard from Gustav (later Gershom) Schocken, Salman's eldest son, that Agnon had recently finished a new story. The publishing house was very much interested in publishing this story amongst other texts and invited Agnon to send "all German material."

The two letters to the authors, written only a few days after the book burnings, show that the Berlin Schocken publishing house did not plan to surrender to the anti-Semitic literature politics of the National Socialist regime. On the contrary, Schocken and Schneider were planning into the future. When in June 1933 the works of Martin Buber were taken over from the Lambert Schneider Verlag, it became notable that the initial shock was overcome. In the summer of 1933 Schocken and Schneider, together with Martin Buber and Moritz Spitzer, decided on the expansion of the publishing house. Whereas in the first two years of its existence the Schocken Verlag mainly published finished material by S.J. Agnon and Martin Buber, most of it was taken over from the Lambert Schneider Verlag when Schocken assumed the Buber/Rosenzweig Bible translation (Schneider 1969), the year 1933 was a turning point (Schneider 1965).

In the autumn of 1933 the publishing house introduced two new series that instantly became very popular: Schocken Bücherei (Schocken library series), a collection of small volumes similar to the Insel Bücherei; and the yearly Schocken Almanach, which presented the program and new books to its readership. The Bücherei quickly became the most successful series within the publishing house. The 92 issues published in 82 volumes reflect the rich tradition of Jewish literary culture. The house published contemporary German authors such as Karl Wolfskehl, Franz Kafka and Ludwig Strauss, and the Hebrew writer S.Y. Agnon in German translation, works by Martin Buber, Gershom Scholem and Herman Cohen, traditional Jewish texts such as Midrashim and works by ben Maimon in translation, biblical texts in bilingual editions, folkloristic texts such as songs for Shabbat and Eastern European tales, as well as historical works and biographies of important Jewish figures.

3 Letter Lambert Schneider to Gershom Scholem, 23 May 1933, in: National Library of Israel Archive (henceforth NLA) Arc. 41599 (folder 1).

4 Letter Lambert Schneider to Gershom Scholem, 21 January 1933 and letter from Gershom Scholem zu Lambert Schneider, 6 April, both in: NLA Arc. 41599 (folder 1).

5 Letter Lambert Schneider to S.J. Agnon, 13 May 1933, in: NLA Arc 41270. 
Schocken was able to develop his program and to expand the publishing house without any major restrictions from the government. Ironically, the selfimplemented restriction to only publish texts from Jewish authors (there are a few famous exceptions, like the later banned book Die Judenbuche by the non-Jewish author Annette von Droste-Hülshoff) protected the publishing house from interference from the Nazis. The Reich Chamber of Letters (Reichsschrifttumskammer), of which Schocken was a member until summer 1937, did not interfere with the publisher's work. Most publishing houses that exclusively published books of Jewish content could do so without much difficulty. In July 1937 the Schocken Verlag was excluded from the Reich Chamber of Letters but received a permit to continue publishing Jewish books under the condition that it would imprint the addition "Jewish Publishing House" (Jüdischer Buchverlag) in all its publications. Only a number of Jewish publishers, among them Schocken, were henceforth allowed to publish books. Until 1937 economic reasons led to the permission of Jewish publishing houses - the president of the Reich Bank stressed the negative consequences for the national economy - the loss of jobs and foreign currency - if Jews were banned from the trade. After the summer of 1937 and the ghettoization, the Nazis believed that Jewish books would only be read by Jews and therefore did not pose an immediate danger to the desired völkisch culture (Barbian 2010, 224, 230f.).

Publishing houses that specialized in Jewish literature, including the Jüdische Verlag, the Jüdische Rundschau, the Hebrew publishing house Menorah, and the publishing houses J. Kaufmann and M. Lehrberger, were in fact much freer in their choice of what to publish than so-called Arian publishers. The historian Jan-Pieter Barbian has shown that authors and publishers were subject to fierce oppression when they published works by unwanted authors. By means of brutal intimidation the NS-state contained deviant behaviour. Strategies to avoid reprisals included self-censorship, political restraint, and exclusion of undesired authors. Only a very small minority of authors and publishers exercised resistance or even open protest (Barbian 1995, 405-409). Schocken not only continued producing Jewish books but also published texts that openly criticized the NS-state and its fascist and anti-Semitic politics (Mahrer 2016). I will refer to the oppositional aspect of Schocken's publishing program in the following section.

Work conditions for exmployees of the Schocken publishing house were very challenging. The production of Jewish books during the early years of the NS-regime was not a simple task, and the production of books that met Salman Schocken's high standards was even more difficult. Salman Schocken strove in all his endeavours for the highest quality possible. Indeed, the nexus between functionality and aesthetics was the hallmark of his public persona (Mahrer 
2015b). The first-ever book he published more than a decade before he founded the publishing house set the example for his future work. In 1914 he gave all convention delegates at the Zionist Federation of Germany's annual meeting a volume of Theodor Herzl's Zionist Congress speeches. Schocken had the volume printed at the Offizin Drugulin in Leipzig. "It was," wrote Kurt Blumenfeld, "the first Zionist book that fulfilled the highest artistic standards of modern printing technique" (1962, 93). Blumenfeld, secretary of the World Zionist Organization, recalled an even earlier meeting when Schocken showed him a well-designed advertisement for his department store. Schocken said, "Here you see my position and opinion regarding print. In principle, no more than a quarter of a page. Not much text, the empty spaces redesigned, and the most important element: typefaces whose clarity is impressed on the mind" (Blumenfeld 1962, 93).

Schocken maintained that the setting and content of books must complement each other. This becomes visible in the Schocken Bücherei series. Despite the unified external design, $11 \times 19 \mathrm{~cm}$ size and jackets in a single color, the width of the pages in the series varied, as did the typography used. Thus, for example, Martin Buber's book on the Baal-Shem Tov and Ludwig Strauss' book of stories were printed in old-fashioned lettering - the former in Dutch lettering dating from 1670 and the latter with red capitals at the head of each chapter, giving it an old appearance - while Heinrich Heine's Der Rabbi von Bacherach (The Rabbi of Bacharach) was given a modern look, accentuated by black-and-white illustrations. Another special book whose richness and complexity were not belied by the monochrome cover common to the series was Joseph und seine Brüder (Joseph and His Brothers). The pages of the text were not bound by the cover; rather, they were inserted as a booklet in an envelope attached to the cover, as were illustrations by an unknown Russian artist. The Passover Haggadah was a model of bilingual typographical design. Hebrew and Latin characters were juxtaposed in the notes, and despite the stylistic difference between them and the difference in the direction of reading, the notes appear fluent and coherent. ${ }^{6}$ This book was the only one in the series that opened from right to left in keeping with the direction of Hebrew script (Mahrer 2015a).

Although the books were produced in a short period of time, Salman Schocken took pains to produce each one; was careful about appearance and supervised pagination. For Spitzer and Schneider, who were responsible for all the organizational tasks such as communication with authors, authorities, printers and suppliers, as well as reviewing and translating manuscripts, book

6 The book was put together by Spitzer with the help of the professional compositor Max Malte Müller. 
production was not a simple undertaking. Even in 1938, under immense pressure from the National Socialist regime, they managed to publish twenty-five books. In August of that same year, Schneider was forced to leave the publishing house because he was considered "Aryan" and was therefore no longer allowed to work for a Jewish patron and publishing house.

The history of the Schocken Verlag not only shows that producing Jewish books in the first half of the Nazi dictatorship was feasible but is also a testament to the fact that business contacts between Jews and non-Jews remained still possible. Lambert Schneider, managing director of the publishing house, was a German non-Jew. His collaboration with Jewish authors such as Franz Rosenzweig and Martin Buber extended over many years, and his expertise in Jewish literary culture was widely acknowledged. ${ }^{7}$ The books produced between 1933 and 1938 were therefore also a means of cross-cultural communication. They built a bridge over the abyss that the NS-state created between Jews and non-Jews.

The cooperation between the publishing house and the printers is a strong example of this type of bridge-building. ${ }^{8}$ Schocken worked first and foremost with the Leipzig-based printing houses Haag-Drugulin, Poesche \& Trepte, and Oswald Schmid. None of the owners of these houses were Jewish, yet they continued working with Schocken. Schocken not only printed books in German but also created a full section in Hebrew, which included books addressed to an academic readership. These works were almost exclusively set at Haag-Drugulin, which had a special division for foreign-language prints (Schneider 1969, 192-202). Schneider remembered that Ernst Keller, owner of Haag-Drugulin, was proud to be able to produce "beautiful Hebrew prints" and that he was happy to try out new things together with the Schocken Verlag (Schneider 1969, 189-202).

A major challenge was posed by bilingual editions, which, on the one hand, made the work of the publisher's staff and the printing presses more difficult, yet, on the other hand, encouraged them to think in new, experimental ways (Tamari 1994, 327-346). Particularly complex projects required the expertise of Max Malte Müller, who was instrumental in achieving the much-admired typography of Schocken Verlag. Müller, a religious socialist and friend of Gustav Landauer, for

7 Despite Schneider's fascinating life story and his many achievements in the German (Jewish) publishing history, no biography of Lambert Schneider has been written. He did, however, publish an autobiography that gives some insight into his public and private life. See Schneider (1965).

8 Unfortunately, a large part of the correspondence between the publishers and printers was lost. It is not clear whether the documents were left behind in Germany when the publishing house was forced to close down or whether they were lost when sent to Schocken's offices in Jerusalem. 
whom he produced the socialist-cum-anarchist publication Der Sozialist (The Socialist), was a highly skilled and talented typesetter. ${ }^{9}$ After World War One he worked for Jakob Hegner in Hellerau, Dresden, and after Hegner's bankruptcy for Heinrich Mercy Son in Prague, where amongst other titles volumes five and six of Schocken's Kafka editions were printed (Dahm 1979, 394).

The difficulty of printing Hebrew books was a recurring theme at staff meetings, and the proposed solutions were creative. One idea was to set up a Hebrew printing press in Germany; Müller had already collected materials with this aim in mind, ${ }^{10}$ but failed to realize it due to the overly high cost. ${ }^{11}$ Another plan was to move the printing operations to Poland. It is unclear why this plan did not go through. Another idea, thoroughly considered but likewise never realized, was the establishment of a printing press in Palestine. ${ }^{12}$ The plan was for Müller to prepare a disposition and for Henri Friedlaender, who had worked as a typesetter with Müller at the Hegner publishing house, to serve as the technical director of the new printing press. ${ }^{13}$ Yet the collaboration between Schocken and Friedlaender never materialized, and steps toward the realization of the idea are not mentioned in existing documents. In any case, all of these ideas reveal that tension in Germany was growing, pushing the Schocken Verlag to search for printing venues outside the country.

Despite harsh conditions, book production brought together people with a shared passion. Schocken's bibliophilic ideas were picked up by his staff. For example, Moritz Spitzer designed a number of books himself and later became an important figure in the printing scene in Palestine/Israel (Wardi 2015). The Schocken publishing house together with the presses and the typesetters constituted an island of professionalism during stormy times. They became, as Howsam has stated, mediators of relationships between people who, according to the prevailing ideology, should no longer have been in contact.

\footnotetext{
9 There is not much information on Müller's work and life other than the few pieces which can be found in Lambert Schneider's autobiography. See Schneider (1965, 51-55). Schneider and Müller had their refusal to serve in Hitler's army in common. Whereas Schneider deserted Müller chose a more tragic solution: when drafted for the army he committed suicide.

10 Correspondence from 1935, SchA 851/822; see also Grundlegende Bearbeitung für eine Druckerei von Herrn M. Müller, 1936, ibid.

11 Report for Mr. Schocken from Dr. Schneider, 16 January 1936, ibid.

12 SchA 351/821 (Pläne Druckerei Palästina).

13 This was the outcome of the staff meeting in Zurich between Salman Schocken and Lambert Schneider on 5-6 March 1936, SchA 331/12.
} 


\title{
3 Giving German Jewry a voice: Selected texts from the Schocken Verlag, Berlin
}

\begin{abstract}
Die Bücherei des Schocken Verlages will in allmählichem Aufbau aus dem fast unübersehbaren und häufig unzulänglichen Schrifttum aller Länder und Zeiten in sorgfältiger Auswahl dasjenige darbieten, was den suchenden Leser unserer Tage unmittelbar anzusprechen vermag.
\end{abstract}

[The Schocken Library aims to present, gradually, a careful selection from the immense and often inaccessible literature of all countries and epochs that will appeal directly to the searching reader of our day.] (Translated by Rachel Seelig)

This quote from an advertisement for the newly introduced 1933 Schocken Bücherei series stands, so Salman Schocken said in an introduction to a neverpublished history of his publishing endeavours, for the work of the Berlin Schocken publishing house in general. ${ }^{14}$ Schocken's objective was to bring "assimilated German Jewry" back to its roots. He was not a religious man, and hence did not view religious traditions as the core aspects of Judaism. For him, rather, culture was the essence of Judaism. He portrayed himself as a man who returned to his Jewish roots by reading Jewish books, gaining access to his own tradition through literary culture. As a man who struggled until the end of his life to master the Hebrew language, he understood that he had to offer translations of the Hebrew writings if he wanted German Jews to read traditional texts; German Jewry perceived his efforts in a positive manner. Although no sales figures survive, the high distribution rate and the fact that a fair number of the Schocken Bücherei volumes appeared in more than one edition demonstrate the popularity of these small books.

Schocken sought to offer his readers "carefully selected Jewish literature from all countries." In order to fulfil this promise, Schocken called upon his editor, Moritz Spitzer, to prepare two volumes every month, a request that was almost impossible to meet. Despite his employee's complaints, Schocken insisted on this high volume of production, even when the strict policies of the National Socialists made work in the publishing house more difficult. As onerous and anxiety-inducing as it must have been for Spitzer and Schneider, Schocken's high standards and persistence were no doubt responsible for producing the Bücherei as we know it today.

14 SchA 30 (Vorwort). 
Books and texts are not only transmitters of culture but also vehicles for community-building. According to Benedict Anderson, people who read the same books around the same time constitute a community (Anderson 2006, 64f.). Such a community was formed by the publications of the Schocken Verlag. It was Salman Schocken's expressed goal to offer assimilated German Jews access to their cultural roots by providing them with accessible Jewish texts. Looking at these texts, which include prose and poetry, songs and folk tales, as well as biblical and midrashic texts, it is clear that he succeeded in making Jewish literary culture available to a broad readership. But close reading of the texts in their historical contexts of publication demonstrates another important factor: some, mainly those of religious origin, represented an outright criticism of the National Socialist regime and its inhuman stance against the Jewish people in Germany.

No written records exist that might indicated when and why Schocken, Schneider, Spitzer and Buber decided to criticise Nazi politics, but the first examples appear as early as fall 1933. When launching the new series of the Almanach, the editor, Moritz Spitzer, decided to open it with a text by Martin Buber, quoted here in full:

Der jüdische Mensch von heute ist der innerlich ausgesetzteste Mensch unserer Welt. Die Spannungen des Zeitalters haben sich diesen Punkt ersehen, um an ihm ihre Kraft zu messen. Sie wollen erfahren, ob der Mensch ihnen noch zu wiederstehen vermag, und erproben sich am Juden. Wird er standhalten? Wird er in Stücke gehen? Sie wollen durch sein Schicksal erfahren, was um den Menschen ist. Sie machen Versuche mit dem Juden, sie versuchen ihn. Besteht ers? ... Etwas ist geschehen. Statt des einen Wesens, an dem die Spannungen des Zeitalters sich auslassen wollten, sind zwei zu schauen, - ein zerfallendes und ein unbezwingliches. Eins, das Licht ausgibt wie ein phosphoreszierender Sumpf, und eins, das Licht ausgibt wie der Orion. Aber dieses steht für jenes ein. Dieses sagt von jenem: Das bin ich. Es streckt sich über es hin, es deckt es, es duldet, was zu dulden ist. Und wenn eure Probe bestanden sein wird, Spannungen des Zeitalters, werden nicht mehr zwei dasein, sondern einer, der Überwinder. (Buber 1933/34, 5) ${ }^{15}$

[The Jewish person of today is he most exposed person in our world. The tensions of the era have chosen this moment to measure their strength on him. They want to know whether man can still resist them, and test themselves against the Jew. Will he withstand? Will he fall to pieces? Through his fate they to seek to learn the state of humanity. Will he survive? ... Something has happened. Instead of one being, against which the tensions of the era wished to rail, two appear: one decaying and the other invincible. One that emits light like a phosphorescent swamp, and one that emits light like the Orion. But this represents that one. It says about the other: this is me. It stretches over it, covers it, tolerates what is to be tolerated. And once your test has been overcome, tensions of the era, there will no longer be two, but one, the one who overcomes.] (My translation)

15 In 1936 the same text was published a second time by the Schocken Verlag (Buber 1936b). 
This short text was the opening of the first Almanach, published on the occasion of Rosh Hashana in 1933. Even though Buber refrains from naming the ones responsible for the "tensions of the time" (die Spannungen des Zeitalters), the text could hardly be more specific. It was bold of Schocken, Schneider, Spitzer and Buber to publish this text in the fall of 1933, for it not only offered German Jews comfort but also warned non-Jews not to be seduced by the "phosphorescent swamp" (phosphoreszierender Sumpf) of National Socialism. Indeed, the text is addressed to Jewish and non-Jewish readers alike. Just as the sirens sought to seduce Odysseus with their beautiful song, only to destroy him, Buber's proverbial marsh radiates a seductive light that attracts the masses, but will ultimately lead them to ruin. While its offers consolation to the Jews, it expresses a stark warning to all others. Despite this apparent perspicuity of the text, it was neither objected nor banned by the Nazi authorities.

The 1934 published text Zwiesprache (Dialogue) (Buber 1934) was a reissue of Ich und Du (I and Thou, 1929, 201-222), which was published in 1923 in Die Kreatur (The Creature). Die Kreatur, an important cultural magazine in the Weimar Republic, was published by Martin Buber, Joseph Wittig and Viktor von Weizsäcker. The quarterly laid its focus on the dialogue between Judaism and Christianity on the basis of mutual tolerance an absolute equality. In 1934, the decision to republish as an independent publication a text with such provenance, a text that stemmed from a journal which promoted the equality of Jews and Christians, was a clear affront to the ruling power, which strove to disrupt any form of dialogue between Jews and non-Jews. Buber, however, did not only republish his 1923 text, which emphasized the deep connection between adherents of the two religions, but also added some thoughts on the current political situation. In both versions of the essay he explored the concepts of dialogue and companionship on different levels. In the 1934 version he added an analysis of the present times:

Die Männer des Kollektivums blicken mit überlegner Gebärde auf die ,Sentimentalität‘ der nächstvergangenen Generation, des Geschlechts jener ,Jugendbewegung' nieder. Damals befasste man sich weitläufig und tiefsinnig mit der Problematik aller Lebensbeziehungen, man intendierte ,Gemeinschaft' und problematisierte sie zugleich, man kreiste in Kreisen und kam nicht vom Fleck. Jetzt aber wird kommandiert und marschiert, denn jetzt gibt es die ,Sache‘. Man ist aus den Irrgängen der Subjektivität auf die zielgerichtete Strasse des Objektivismus gelangt. Doch wie dort eine Pseudo-Subjektivität, da es an der elementaren Kraft des Subjektseins fehlte, so besteht hier ein Pseudo-Objektivismus, da man nicht einer Welt sondern einer weltlosen Parteiung eingefügt ist. Wie dort alle Loblieder auf die Freiheit ins Leere gesungen wurden, weil man nur die Freimachung von den Bindungen, nicht aber die Befreiung zur Verantwortung kannte, so sind auch hier die edelsten Hymnen auf die Autorität ein Missverstand, weil sie faktisch nur die erredete, erschriene Scheinautorität stärken, hinter der sich eine in die mächtigen Faltenwürfe der Haltung gewandte Haltlosigkeit birgt, die echte Autorität aber, die jene Hymnen feiern, die des echten Charismatikers in seiner steten Verantwortung zum Herrn der Charis, dem politischen Raum der Gegenwart unbekannt geblieben ist. (Buber 1934, 64f.) 
[The men of the collective look down on the "sentimentality" of the last generation, the generation of the "youth movement," with a gesture of superiority. Back then one dealt extensively and in depth with the challenge of all human relations; one sought "community" and simultaneously problematized it, going in circles and remaining fixed in one spot. Now, however, we have commands and marching, for now there is the "cause." One has emerged from the meanderings of subjectivity and arrived at the goal-oriented street of objectivity. Yet, just as there was a pseudo-subjectivity, since an elementary force of the subject-being was lacking, so we find here a pseudo-objectivity, since one is integrated not into the world but rather into a worldless faction. Just as the hymns of freedom were sung into the void because one only knew freedom from bonds and not freedom with responsibility, so too the noblest hymns to authority are misunderstandings, for they only strengthen the pseudo-authority, behind the mighty drapery of which hides a stance of instability. However, the true authority that those hymns celebrate, that of the real charismatic in his constant responsibility to the Lord of the Charis, remains unknown within the present political sphere.] (Translated by Rachel Seelig)

Buber and the publishing house took a considerable risk by publishing these lines. In no other publication of the Schocken Verlag was the National Socialist regime attacked in a similar manner. Buber not only denounces the faulty ideology and the misdirection of the marching masses but also calls the authorities an “authority phantom” (erredete, erschriene Scheinautorität), which lacks any substance whatsoever.

Who is the audience of this text? Unlike the previous passage, no words of solace can be found in this essay. The text and the initial context of publication do, of course, allude to the possibility of equal coexistence between Jews and Christians; this is not so of the 1934 edition quoted above. One cannot help but think that it is indeed written for a non-Jewish audience. Buber's text opened, one can argue, room for dialogue between two societies that were no longer allowed to speak with each other.

The memoirs of Lambert Schneider indicate that the Schocken publications were extremely popular with certain groups of non-Jewish readers. Although so-called Aryan bookstores were officially prohibited from selling Jewish publications, many still did so illegally (Schneider 1965, 42). Furthermore, Jewish bookstores were freely accessible, and all the books of the Schocken publishing house could be ordered directly by mail.

The self-chosen limitation to publish Jewish books exclusively made it possible for the Schocken Verlag to print such texts. According to Schneider's memoirs, the National Socialist regime attempted to banish the publishing house into a metaphorical ghetto and thereby enabled them to publish critical and oppositional texts. Another text by Buber, on the occasion of Rosh Hashana 5696 (1935), entitled Erkenntnis tut not (knowledge is necessary), reveals that the 
publishers targeted a non-Jewish audience. In this three-page essay Buber dwells on the space of dialogue. He writes:

\begin{abstract}
Es gibt den Raum nicht mehr, in dem wir zu den anderen sprechen und von ihm vernommen werden können. Es gibt den Dialog nicht mehr. ... Der Raum ist taub geworden. Und doch auch wieder nicht. Denn was wir im ertaubten Raum der Öffentlichkeit zu uns selber, nur noch zu uns selber sagen, kann ja doch von jedem Beliebigen, dem es gar nicht zugedacht war, gehört werden. Wohl, so werde es gehört. (Buber 1935/36, 11-14)
\end{abstract}

[The space no longer exists where we can talk to and be heard by others. Dialogue no longer exists. ... The space has become deaf. And yet, it has not. For what we say in the deafened space to ourselves, and only to ourselves, can be heard by everyone, by those it was not meant for at all. Surely, so it can be heard.] (My translation)

In these few lines, Buber makes clear that in autumn 1935 the room for dialogue no longer existed. State-organized terror against Jews reached a new level. In March of that year the president of the Reich Chamber of Letters (Reichsschrifttumskammer) issued a ban on Jews working as writers in Germany; by September, the so-called Nuremberg Laws were introduced. With these laws the National Socialists institutionalized their anti-Semitic ideology just two weeks before the Jewish New Year. For Buber, who wrote the essay Erkenntnis tut not for the Schocken almanac, the events of 1935 had a deep impact; in his view, the new racial laws put an end to the German-Jewish dialogue. And yet, as Buber noted, everyone can eavesdrop on the inner-Jewish soliloquy. The self-talk, the thoughts that can henceforth only be uttered to oneself, as Buber notes, were in the case of the Schocken publishing house so pronounced and belligerent that they had to be heard beyond the innerJewish sphere. Buber alludes to the fact that, by law, texts of Jewish origin or authorship could only be published by Jewish publishing houses. The literature politics of Nazi Germany tried to confine Jewish literary culture to a Jewish readership, making it an inner-Jewish matter only - or as Buber puts it, reducing it to Jewish self-talk. However, Buber also states that this self-talk, texts written by Jews, did find a readership beyond Jewish circles.

Despite Buber's notion that the window for dialogue between Jews and nonJews had closed, it is clear that the Schocken Verlag publications were bearers of communication between the two groups. In times when direct communication and open criticism put people at risk, the published word took over the task of accusing and explicating. Books and periodicals served as mediators and as the space within which where dialogue continued to unfold. They provided German Jewry with a safe space of self-assurance while also opening a channel of communication between two groups who had been separated by racial policies and laws. 
Thus far, I have highlighted three essays by Martin Buber, which exemplify the manner in which the Schocken Verlag openly criticized the National Socialist regime and its ideology. However, if we analyse the whole corpus of the Schocken publishing house, it becomes clear that the regime was accused and criticized primarily in another genre: biblical and religious texts served as the main sources of political critique. Old Hebrew script translated into German provided German Jewry with a powerful voice.

The very first volume of the Schocken Bücherei opened with a biblical quote taken from Isaiah 40.1: “Tröstest tröstest mein Volk / spricht euer Gott” (Comfort, comfort my people / says your God) (Buber 1933, 4). In 1933 the Jews of Germany were in need of solace, and the ancient biblical text in the translation of Martin Buber and Franz Rosenzweig fulfilled this need.

Du aber,

Jissrael, mein Knecht, Jaakob, den ich wählte, du Samen Abrahams, meines Liebenden!

du den ich erfasste von den Rändern der Erde her, von ihren Achseln her habe dich ich gerufen

und sprach zu dir:

Mein Knecht bist du!

Gewählt habe ich dich einst

und habe dich nie verworfen, -

fürchte dich nimmer,

denn ich bin bei dir, starre nimmer umher, denn ich bin dein Gott, ich stärke dich, ich helfe dir auch, ich halte dich auch mit der Rechten meiner Wahrhaftigkeit. (Buber 1933, 8)

[But you, Israel, my servant, Jacob, whom I have chosen, the offspring of Abraham, my friend; you whom I took from the ends of the earth, and called from its farthest corners, saying to you, "You are my servant, I have chosen you and not cast you off"; fear not, for I am with you; be not dismayed, for I am your God; I will strengthen you, I will help you, I will uphold you with my righteous right hand.] (Isaiah 41:8-10) ${ }^{16}$

16 English translations of biblical quotations are taken from the English Standard Version. 
The book of Isaiah constitutes the first of three large collections of prophetic books: Isaiah, Jeremiah, and Ezekiel. The first part, chapters 1-39, date the prophecies of Isaiah ben Amoz in the mid-eighth century B.C.E. The abrupt shift from oracles of doom (chapters 1-9) to prophecies of consolation, which refer to the historical reality of the return from exile, has led commentators to believe that their origins date two centuries later (Fishbane 2002, 409). Buber chose for the first volume of the Schocken Bücherei verses 40-55, a "collection of prophecies of comfort emphasizing imminent redemption" in verses 40-48, as well as prophecies emphasizing reconciliation with God and physical restoration (verses 49-55) (Fishbane 2002, 410). The book of Isaiah is full of metaphors and rich in symbols that lend it "to being understood as an open text." (Gray 2006, 7f.) Jewish tradition is characterized by the emphasis on the need for constant interpretation of the Bible. According to rabbinic sources, human interpretation started at the moment of the revelation at Mount Sinai and is thus part of the revelatory itself (Zetterhom 2013).

What Buber offered his readers was not an interpretation of the Biblical text per se, but, by choosing these exact verses - prophesies of consolations, promises of redemption, reconciliation with God and physical restoration - he provided them with a text that speaks directly to them. "Fear not, for I am with you; be not dismayed, for I am your God; I will strengthen you, I will help you, I will uphold you with my righteous right hand" (Isaiah 41, 10-11). In the fall of 1933 these words gained an imminent significance for Jewish readers, for they promised the despair of destruction would be reversed. The feeling of being at the mercy of the Nazi persecutors is juxtaposed by the eternal promise of God to stand by his people.

As stated in a prospect from 1935, the Schocken Library series aimed to provide "the searching reader of today" with carefully selected Jewish texts from all countries and all times that address their imminent needs. By publishing noted editions of biblical or other religious texts translated into German the publishers honored their promise.

Promising imminent fulfilment of prophecies of restoration through repeated references to God was only one aspect of this and other publications in the Schocken Verlag. In verse 41:11 the Biblical text promises revenge: "Behold, all who are incensed against you shall be put to shame and confounded; those who strive against you shall be as nothing and shall perish." Whereas the previous lines are directed to the despairing Jewish people, this verse was intended to invoke the wrongdoing of the Nazis. The openness of the text, as Gray stated, as well as the tradition of constant interpretation of the biblical text, allows the contemporary reader to make a connection between the ancient religious text and their own world. It also allowed the authors and the publishers of the Schocken Verlag to level criticism at the Nazi regime. 
One last and rather peculiar example from the publications of the Schocken Verlag is volume 51 of the Schocken Bücherei (1936), which contains twentythree psalms of thanksgiving and lamentation translated into German, with an introduction by Martin Buber. What makes the publication stand out from other editions of the psalms is Martin Buber's choice to rearrange the sequence. He ordered them in a manner that created a direct link between the biblical text and the presence of the reader (Buber 1936a, 7). Starting with Psalm 130, which begins, "Lord, I call to you from the depths," a psalm that refers to the direct dialogue between man and God, Buber focused on the living deity rather than on the demand for the cessation of misery. The lamentation reads, "Why have you forgotten me?" rather than, "Why must I suffer?” After a short revolt provoked by the almost unbearable torment expressed by the question, "How much longer?" man submits to the divine plan. The hope of liberation and redemption awakens towards the end of the text when, finally, the weak triumphs over the perpetrator.

Buber's rearrangement of the psalms creates a new text in its own right. The biblical text of thanksgiving and lamentation is transformed into a passionate and belligerent version, as the following excerpt from Psalm 74 illustrates:

Ist doch Gott mein König

von ureinst her,

der Befreiung wirkt

im Innern des Erdlands!

Du,

du zerbrocktest mit deiner Macht das Meer,

du zerbrachst Drachenhäupter überm Wasser,

$\mathrm{du}$,

du zerstücktest die Häupter des Lindwurms,

du gabst ihn als Frass dem Wüstenspuk-Volk,

$\mathrm{du}$,

du erspaltetest Quell und Bachtal,

du,

du vertrocknetest urständige Ströme.

Dein ist der Tag,

dein auch die Nacht,

$\mathrm{du}$,

du errichtest Geleucht und Sonne,

$\mathrm{du}$,

du stelltest alle Marken des Erdballs auf, -

Sommer und Winter,

$\mathrm{du}, \mathrm{du}$ bildest sie. 


\author{
Gedenke dies: \\ der Feind höhnt DICH! \\ schändlich Volk schmähn deinen Namen! \\ Nimmer gib dem Wildlebenden \\ die Seele deiner Turtel! \\ das Leben deiner Gebeugten, \\ nimmer vergiss es in die Dauer! \\ Blick auf den Bund! \\ denn gefüllt haben sich die finstern Plätze des Erdlands \\ mit Triften der Unbill. \\ Nimmer möge sich abkehren müssen \\ der Geduckte beschimpft! \\ der Gebeugte, der Dürftige \\ sollen deinen Namen preisen! \\ Steh auf, Gott! \\ streite deinen Streit! \\ gedenke deiner Verhöhnung \\ durch den Schändlichen all den Tag! \\ Vergiss nimmer \\ die Stimme deiner Bedränger, \\ das Toben der gegen dich Aufständischen, \\ das stetig hinansteigt! (Buber 1936a, 27-29)
}

[Yet God my King is from of old, working salvation in the midst of the earth. You divided the sea by your might; you broke the heads of the sea monsters on the waters. You crushed the heads of Leviathan; you gave him as food for the creatures of the wilderness. You split open springs and brooks; you dried up ever-flowing streams. Yours is the day, yours also the night; you have established the heavenly lights and the sun. You have fixed all the boundaries of the earth; you have made summer and winter. Remember this, O LORD, how the enemy scoffs, and a foolish people reviles your name. Do not deliver the soul of your dove to the wild beasts; do not forget the life of your poor forever. Have regard for the covenant, for the dark places of the land are full of the habitations of violence. Let not the downtrodden turn back in shame; let the poor and needy praise your name. Arise, O God, defend your cause; remember how the foolish scoff at you all the day! Do not forget the clamor of your foes, the uproar of those who rise against you, which goes up continually!] (Psalm 74: 12-24)

Psalm 74 deals with the destruction of the first temple in 587 BCE and has an immense potential for biblical and post-biblical interpretation (Cordes, Hansberger and Zenger 2002). The readers of the Schocken Bücherei were generally neither educated in Biblical exegesis nor in rabbinical literature, but even without a background in traditional Jewish exegetic texts, a Jewish reader in 1936 could make a connection between the Psalm and his own situation. 
The first part of the psalm, which is not quoted here, speaks of a deep rupture in the relationship between the Jewish people and its God. Verses one and eleven each start with a why-question: The first ("Why do you cast us off forever?") laments the fact that God has turned away from its people, but already the second ("Why do you hold back your hand?") is in fact a plea to punish Israel's enemies. The second part of the psalm (verses 12-17), which stand out with the stylistic rhythmical repetition of the personal pronoun "you" at the beginning of each verse, proclaims the omnipotence of the Jewish God as the savior ("You divided the sea by your might; you broke the heads of the sea monsters on the waters. You crushed the heads of Leviathan; you gave him as food for the creatures of the wilderness.") and as the creator ("Yours is the day, yours also the night; you have established the heavenly lights and the sun. You have fixed all the boundaries of the earth; you have made summer and winter.”)

The text is characterized by a steady increase and culminates in the plea to God to use his omnipotence to destroy his and his people's enemies. “Arise, $\mathrm{O}$ God, defend your cause; remember how the foolish scoff at you all the day! Do not forget the clamour of your foes, the uproar of those who rise against you, which goes up continually."

The initial lamentation of the rupture between God and the Jewish people in the first verses turns toward the end of the psalm into a forceful appeal to God to take revenge. In Buber's edition psalm 74 is followed by psalm 64, which relates thematically to the previous text. The psalmist pledges for protection from the enemies, who are here described in some detail: "Hide me from the secret plots of the wicked, from the throng of evildoers, who whet their tongues like swords, who aim bitter words like arrows, shooting from ambush at the blameless, shooting at him suddenly and without fear. They hold fast to their evil purpose; they talk of laying snares secretly, thinking: 'Who can see them?'” The enemy is described as a force ambushing the innocent trying to hide its evilness. When reading this text in the context of the year 1936 one cannot help but see allusions to the 1936 Summer Olympics taking place in Berlin. The Nazi government saw the games as an opportunity to camouflage its racist policies and present itself to the world as a peaceful and tolerant country. Most anti-Jewish signs were removed - temporarily and the newspapers toned down their racist and anti-Semitic rhetoric.

Texts like these resonated strongly with their German-Jewish readers, who could see parallels between their own world and that of the biblical texts. Their fears of being abandoned are addressed and countered with a promise of an omnipotent and revenging power. The millennia-old Hebrew text gained in Buber's translation and arrangement new meaning in the context of 1930s Germany. It spoke to a secular and assimilated population that, under other circumstances, might not have looked for solace and support from biblical sources. In so doing 
the text turns into a dialogical space of support for the ill-fated and tormented Jews of Germany.

The few lines from psalm 64 show yet another function of Biblical texts published in the Schocken Verlag: an open but at the same time hidden critique of the Nazis. By means of the psalm Buber warns his readers of the threat the Nazis and their policies pose. On the surface, the Schocken Verlag did nothing other than publish biblical texts in a special edition, when in fact the selection of the verses read in the context of Nazi oppression took on a new meaning: it is no longer the demolition of the temple that is being lamented but the destruction of German-Jewish life, not the Babylonians who should be punished by a vengeful God but the Nazis, the enemies of the present. The biblical text served to camouflage an angry critique.

\section{Material objects and written text - a conclusion}

The books of the Schocken Verlag Berlin gained great importance during the early years of the National Socialist dictatorship. In the contemporary Jewish press their significance for German Jewry was praised in book reviews and editorial articles alike (Schreuder 1994). As objects, as printed books, they served as visible and touchable reminders of the rich Jewish culture that was being destroyed by Nazism while also bearing witness to the persistence of Jewish life in Germany, to the fact that German Jews were still part of a larger society. The processes of typesetting, printing, and binding included the Jewish publishers in the circle of book production that was not organized by religious affiliations and racial denomination, but by the common interest in the book as an object of material culture. ${ }^{17}$ Typesetting has its own rich history and is a culture in its own right. The high demands Salman Schocken placed on the aesthetics of his books led to close cooperation between his staff and the typesetters and printers they worked with. This places the Schocken books in the general history of book design and typesetting but also in the circle of communication between likeminded professionals. The bilingual German-Hebrew editions were the most challenging to set. Even for experienced typesetters, combining the Latin and Hebrew letters in a balanced manner was a difficult task. Some of the bilingual

17 I owe my knowledge about typesetting and book design to Ada Wardi, with whom I had the pleasure of working in an exhibition project on three German-Jewish graphic designers who learned their profession in Germany and became important for Modern Hebrew type and book design in the State of Israel. 
editions were particularly successful in this regard. For example, in volume 54, the Passover Haggada, edited and commented on by E. D. Goldschmidt, the proportion between the Hebrew Drugulin typeface and the Latin Bodoni-Antiqua is well balanced.

On the textual level, the German translation of biblical and post-biblical texts opened up a possibility to speak up and be heard. By translating the Hebrew of religious tradition into contemporary German, the texts were transformed into a means of camouflaged resistance. The old texts had previously not played an important role for many of their assimilated and secular readers, but became accessible and relevant again. By this, they lent their voice to the brutally silenced Jews of Germany. The books of the Schocken Verlag indeed became "living creatures," as Milton stated in the mid-seventeenth century. They played an active role not only in transmitting ideas but also in unifying human beings.

\section{Works cited}

Anderson, Benedict. Imagined Communities. Reflections on the Origin and Spread of Nationalism. London: Verso, 2006 [1983].

Barbian, Jan-Pieter. Literaturpolitik im “Dritten Reich". Institutionen, Kompetenzen, Betätigungsfelder. Überarb. und aktualisierte ed. München: Deutscher Taschenbuch Verlag, 1995.

Barbian, Jan-Pieter. Literaturpolitik im NS-Staat. Von der "Gleichschaltung" bis zum Ruin. Überarb. Ausgabe. Frankfurt a.M.: Fischer Taschenbuchverlag, 2010.

Blumenfeld, Kurt. Erlebte Judenfrage. Ein Vierteljahrhundert deutscher Zionismus. Hg. und mit einer Einführung versehen von Hans Tramer. Veröffentlichung des Leo Baeck Instituts. Stuttgart: Deutsche Verlagsanstalt, 1962.

Buber, Martin. “Ich und Du.” Die Kreatur 3.2 (1929): 201-222.

Buber, Martin. Die Tröstung Israels mit der Verdeutschung von Martin Buber und Franz Rosenzweig. Bücherei des Schocken Verlages Vol. 1. Berlin: 1933.

Buber, Martin. "Der jüdische Mensch von heute." Almanach des Schocken Verlags auf das Jahr 5694. Ed. Schocken Verlag Berlin: Schocken Verlag, 1933/34. 5.

Buber, Martin. Zwiesprache. Bücherei des Schocken Verlages Vol. 16. Berlin: Schocken Verlag, 1934.

Buber, Martin. “Erkenntnis tut not.” Almanach auf das Jahr 5696. Ed. Schocken Verlag Berlin: Schocken Verlag, 1935/36. 11-14.

Buber, Martin. Aus den Tiefen Rufe ich dich. 23 Psalmen in der Urschrift mit der Verdeutschung von Martin Buber. Bücherei des Schocken Verlages Vol. 51. Berlin: Schocken-Verlag, 1936a.

Buber, Martin. Die Stunde und die Erkenntnis. Reden und Aufsätze 1933-1935. Berlin: Schocken Verlag, 1936b.

Cordes, Ariane, Therese Hansberger, and Erich Zenger. "Die Verwüstung des Tempels - Krise der Religion? Beobachtungen zum Volkslkagepsalm 74 und seiner Rezeption in der Septuaginta und im Midrasch Tehillim." Zerstörung des Jerusalemer Tempels. GeschehenWahrnehmung-Bewältigung. Ed. Johannes Hahn. Wissenschaftliche Untersuchungen zum Neuen Testament. Tübingen: Mohr Siebeck, 2002. 61-91. 
Dahm, Volker. Das jüdische Buch im Dritten Reich. Frankfurt a.M.: Buchhändler-Vereinigung, 1979.

Dahm, Volker. "Anfänge und Ideologie der Reichskulturkammer. Die "Berufsgemeinschaft" als Instrument kulturpolitischer Steuerung und sozialer Reglementierung." Vierteljahreszeitschrift für Zeitgeschichte 34.1 (1986): 53-84.

Darnton, Robert. "What Is the History of Books." Deadalus 111.3 (1982): 65-83.

Fishbane, Michael A. The JPS Bible Commentatory: Haftarot. Philadelphia: Jewish Publication Society, 2002.

Gray, Mark. Rhetoric and Social Justice in Isiah. London, Oxford, New York, New Delhi \& Sydney: Bloomsbury Publishing, 2006.

Hales, John. M. Milton. Areopagitica. Edited with Introduction and Notes. Clarendon Press Series. Oxford: Clarendon Press, 1904.

Howsam, Leslie. Old Books and New Histories: An Orientation to Studies in Book and Print Culture. Toronto: University of Toronto Press, 2006.

Mahrer, Stefanie. "A Microcosmos of Jewish Culture. The 'Schocken Library Series'." The Graphic Design of Moshe Spitzer, Franzisca Baruch and Henri Friedlaender. Ed. Ada Wardi. Jerusalem: Israel Museum, 2015a. 88-105.

Mahrer, Stefanie. "Tradition and Modernity - Salman Schocken and the Aestheticisation of everyday life." The Graphic Design of Moshe Spitzer, Franzisca Baruch and Henri Friedlaender. Ed. Ada Wardi. Jerusalem: Israel Museum, 2015b. 58-71.

Mahrer, Stefanie. "Schreiben aus den Katakomben. Bücher als Widerstand. Der Schocken Verlag Berlin in den Jahren 1933 bis 1938.” Jüdischer Widerstand in Europa (1933-1945). Formen und Facetten. Eds. Julius H. Schoeps, Dieter Bingen and Gideon Botsch. Berlin: De Gruyter, 2016. 222-239.

Milton, John. Areopagitica. A Speech of Mr. John Milton for the Liberty of Unlicenc'd Printong. To the Parliament of England. London: 1644.

Sauder, Gerhard. "Der Germanist Goebbels als Redner bei der Berliner Büchervebrennung.” “Das war ein Vorspiel nur..." Berliner Colloquium zur Literaturpolitik im 'Dritten Reich'. Eds. Horst Denkler and Eberhard Lämmert. Schriftenreihe der Akademie der Künste. Berlin: Akademie der Künste, 1985. 56-81.

Sauder, Gerhard, ed. Die Büchervebrennung. Zum 10. Mai 1933. München: Carl Hanser Verlag, 1983.

Schneider, Lambert. Rechenschaft über vierzig Jahre Verlagsarbeit 1925-1965. Ein Almanach. Heidelberg: Lambert Schneider, 1965.

Schneider, Lambert. “Salman Schocken.” Imprimatur. Ein Jahrbuch für Bücherfreunde 6 (1969): 189-202.

Schreuder, Saskia. “'Inmitten aller Not und aller Angriffe’. Der Schocken Verlag im Spiegel der jüdischen Kritik.” Der Schocken Verlag/ Berlin. Jüdische Selbstbehauptung in Deutschland 1931-1938. Eds. Saskia Schreuder and Claude Weber. Berlin: Akademie Verlag, 1994. 377-395.

Tamari, Ittai Jospeh. “Hebräische Typographie des Schocken Verlags.” Der Schocken Verlag Berlin. Jüdische Selbstbehauptung in Deutschland, 1931-1938. Essayband zur Ausstellung 'Dem suchenden Leser unserer Tage' der Nationalbibliothek Luxemburg. Eds. Saskia Schreuder and Claude Weber. Berlin: Akademie Verlag, 1994. 327-346.

Wardi, Ada. "Moshe (Moritz) Spitzer." The Graphic Design of Moshe Spitzer, Franzisca Baruch and Henri Friedlaender. Ed. Ada Wardi. Jerusalem: Israel Museum, 2015. 75-79.

Zetterhom, Karin. "Jewish Interpretation of the Bible. Ancient and Contemporary." The Bible and Interpretation (2013). Web. http://www.bibleinterp.com/articles/2013/zet378014. shtml [last access: 17.03.2017]. 
Brought to you by | Universitaetsbibliothek Basel

Authenticated Download Date | 3/8/18 12:14 PM 